\title{
Management Of Education Quality Improvement At Education Council Al Washliyah North Sumatra
}

\author{
Dedi Iskandar Batubara, Heri Kusmanto, Arif Nasution, Amir Purba \\ Faculty of Social and Political Sciences, University of Sumatera Utara \\ Medan, Indonesia \\ Email: Dediiskandarbb4@gmail.com
}

\begin{abstract}
This study Aimed to know the planning, organizing, implementing, controlling and evaluating education quality improvement in education council at Al Washliyah, North Sumatra. Qualitative research is used in this study. that is based on the background of the individual as holistically. The technique for collecting the data by using three ways items, namely: interview, observation and document study. Analyzing the data done by four steps items, namely: reduction of data, providing the data, conclusion and verification. The validity of collecting the data is checked by the data validity standards such as trustworthiness, transferability, dependence and certainty.

There are five findings in this study items, namely; (1) The planning improvement of education quality at education council Al Washliyah, started with the arrangement of the workplan through the region forums and work meetings Al Washliyah, North Sumatra, as organization decision maker they do some activities such as education and training, comparative study, Curriculum, the arrangement Alwashliyah curriculum and the improvement of education system in AlWashliyah. (2) Organizing is done in order to the make of education improvement in north Sumatra

Alwashliyah appropriately by dividing four fields based on the function. The four fields are curriculum Alwashliyah / Islamic boarding school in the which the chairman of the I / vice of secretary I is responsible.Vice of Chairman II / Vice of SecretaryIIis responsible with the curriculum of the joint decree (SKB). Vice chairman of III / vice of secretary III is responsible with national education, Vice Chairman IV / Vice of Secretary IV is responsible with higher education. (3) The implementation of education quality improvement in Alwashliyah council has not fully maximum. It can be seen from the implementation of workplanthe which has been made in the forum, can not run well. The implementation of education quality improvement is still incidental and tends to formality. (4) The observation is performed when the activity is on, yet after completing there is no further observations. (5) Evaluating process against education quality improvementat the north Sumatra Alwashliyah council has not worked yet fully optimal due to the unplanned and non-programmed actions.
\end{abstract}

Keywords: Education, Management, Al Washliyah

\section{NTRODUCTION}

Education is considered as the most valuable investment in the form of improving the quality of human resources for the development of a nation. The greatness of a nation is often measured by the extent to which people pursue education. The higher education which is owned by a nation, the more marched the nation. The education quality is not only seen from the grandeur of education facilities, but the extent of the education output can do in the community and become qualified human resources.

There are three factors that lead to low education quality in Indonesia, namely: 1) Policy and

implementation of national education using the approach of educational production function or inconsistent input-output analysis, 2) The education system implemented in a centralized way, 3) The minimal participation of people, particularly the parents of students' in education. ${ }^{1}$

National Education must be managed properly. Tilaar notes that the national education system is a social process which is engineered to achieve national education goals effectively and efficiently by involving the cooperation and participation of the whole society. The national education function, mission and policies to produce high-quality human resources require quality-improvement-oriented education system management. ${ }^{2}$

The improved quality is becoming increasingly important for educational institutions in order to achieve the fullest educational goals and to gain public confidence. Educational institutions must demonstrate that

${ }^{1}$ Husaini Usman, "New Role of Educational Administration centralized system towards a decentralized system", in the Journal of Educational Sciences (February 2001), vol 8, p. 8.

Tilaar, National Education Management. Education Study Future, cet 1 (Bandung: Youth Rosdakarya, 1997), p. 11. 
they are able to provide quality education to the learners. We live in an era of all-round unclear competition. To be closer to improving the quality itself, the authors take us all in the theoretical concepts of the quality.

According to the available data on the Education Council of Al Washliyah, North Sumatra, there are 620 units of schools (madrasah) run by Al Washliyah, ranging from pre-school, elementary school (SD)/Islamic Elementary to High School (SMA) and equal spread in almost each regency/ city in North Sumatra. The amount has put Al Washliyah as a social organization with the highest number of educational institutions in North Sumatra. Based on that number, it takes management and a strong and consistent efforts of all stakeholders in running the organization's work.

Education Council of Al Washliyah, North Sumatra attempted to make some effort to improve the education quality, especially improving the quality of teacher resources such as carrying out trainings, urging teachers to always be active in any activity aimed to improve the quality of teacher, sending teachers to participate in training activities in provincial and national level. In addition, Education Council of $\mathrm{Al}$ Washliyah North Sumatra is also trying to upgrade infrastructure such as seeking funds for completion of infrastructures for target schools in need.

Based on the above explanation, it is necessary to hold a research pertaining to the improvement of the education quality conducted by the Education Council of Al Washliyah, North Sumatra in title of: Management of Education Quality Improvement in Education Council of $\mathrm{Al}$ Washliyah North Sumatra.

\section{A.Formulation of the problem}

Based on the description that has been presented on the background, then that becomes the problem in this research are as follows:

1. How to plan such education quality improvement in Education Council of $\mathrm{Al}$ Washliyah, North Sumatra?

2. How is the implementation of education quality improvement in Education Council of Al Washliyah, North Sumatra?

\section{B.Research focus}

Based on the above background, this study is limited to the management of education quality improvement conducted at the Education Council of Al Washliyah, North Sumatra that is related in some of the following:
1. Planning educational quality improvement,

2. Organizing educational quality improvement,

3. Implementation of education quality improvement

\section{C.Research Method}

This research was conducted using qualitative approach, the approach that is directed to the background and individual in holistic way(whole). So this case should not isolate individual or organization into a variable or hypothesis, but see it as a whole. In addition, the qualitative research is more flexible and possible to change and improve despite of being on the stage of data collection and analysis. According to Bogdan and Taylor (in Moleong) say that qualitative research is a research procedure that produces descriptive data in the form of written or spoken words from people and organizational behavior that can be observed. ${ }^{3}$

Deemed relevant qualitative research used in this study, as it aims to find out how management of education quality improvement in the Education Council of Al Washliyah, North Sumatra either in terms of planning, organizing, implementing, monitoring and evaluation. Consideration of the authors' in using qualitative research methods is based on the ease of which exist in qualitative research methodology is as follows: 1) easier to adjust double fact, 2) this method presents the direct nature of the relationship between researcher and respondent, 3 ) the method is more sensitive and easier to adjust to a lot of together-influence sharpening and patterns of dealt value. 4

\section{D.Informant Research}

For the purposes of the analysis, this section will be described briefly about research informants who were interviewed during the study period. These informants were determined based on the need for information to be obtained as a material this thesis.

The informant is a person who provides information about the circumstances of the setting. So he must have a lot of experience on the research background. He is obliged to voluntarily become a member of the research team, although only in informal. 5

Informants in this study were those who knew and understood about education quality

\footnotetext{
${ }^{3}$ Lexy J. Moleong, Qualitative Research Methodology, cet. 18th (Bandung: Youth Rosdakarya, 2000), p. 3.

${ }^{4}$ Ibid., P. 5.

${ }^{5}$ Ibid., P. 90.
} 
improvement in Education Council of $\mathrm{Al}$ Washliyah, North Sumatra . Usefulness informant for research helps researchers to obtain accurate data that can be obtained in a short time. The informants in the qualitative research method were the ones that seeks to collect data.

The informants in the study were Dariansyah Emde (Chairman of Education Council of Al Washliyah North Sumatra 20032010) and Hashim Shaheed (Chairman of Education Council of Al Washliyah 2011-2015), and administrative/secretariat officials at the Education Council, Muhammad Fauzan Al Washliyah and Syukri Sitompul. The information to be obtained is related to the planning, organizing, monitoring and evaluation to improve the education quality in Education Council of $\mathrm{Al}$ Washliyah, North Sumatra .

The informants involved in this study are some of the principals in Education Council of $\mathrm{Al}$ Washliyah, North Sumatra, namely Silahuddin (MAS Chief Al Qismul'aly Al Washliyah), Amir Hamzah Ritonga (Deputy Head of Curriculum MTs (junior high school).S Ex. Project PGA UNIVA Medan) and Mislan (Head of Engineering SMK 1 Al Washliyah Medan). The aim is to confirm information obtained from the Education Council of Al Washliyah, North Sumatra and obtain information about education quality improvement.

E.Data collection technique

Qualitative research is basically an investigation process that is similar to detective. The investigation will collect the major data and the additional ones. The main data sources in qualitative research are the words and actions, while the written data, photos and statistics is additional. ${ }^{6}$

Data collection techniques in qualitative research is various. The researchers collect data in three ways, namely; interviews, the study documents, and observation.

1. Interview,

The interview is a method of collecting data by asking something to someone who became an informant or respondent. The trick is to converse face to face. Interviews can be done by using the interview or by a question and answer directly.

Departing from the theory above, the researchers collects data through interviews to obtain information about the profile of $\mathrm{Al}$ Washliyah in general and Education Council of Al
Washliyah North Sumatra in particular, on education quality improvement (from planning, organizing, implementing, monitoring and evaluation related to the policies implemented by the Education Council Al Washliyah North Sumatra). Information was obtained through two institutions: from the caretaker of Education Council of Al Washliyah North Sumatra and the representative citizens of target schools Education Council of $\mathrm{Al}$ Washliyah, North Sumatra . Information is obtained with a very open. Through this interview researchers can directly face to face with the people who are directly related to the management of education quality improvement.

2. Observation

These observations represent a researcher's participation in management activities to improve the education quality conducted by the Education Council of $\mathrm{Al}$ Washliyah, North Sumatra to the schools. Activities that will be observed is planning, organizing, monitoring and evaluation of policy implementation in Education Council of $\mathrm{Al}$ Washliyah North Sumatra in terms of education quality improvement.

This observation process carried out carefully with the aim to acquire higher validity (validity) and reliability (accuracy) of observation result. Observations are intended to directly pay attention to process management of education quality improvement in Education Council of Al Washliyah, North Sumatra with first prepare written guidelines on aspects that will be observed.

\section{Study Documents}

The official document is divided into internal documents and external documents. Internal documents such as memos, announcements, instructions, rules of a specific community institutions that are used in their own circles - including the meetings minutes or reports, a leader's decision of the office, etc. ${ }^{7}$ Documents can thus provide information about the state, rules, discipline, and could provide clues about leadership style. These internal documents can be obtained information about $\mathrm{Al}$ Washliyah in general and Education Council of $\mathrm{Al}$ Washliyah in particular. Additional information will also be obtained such as board meetings of Education Council Al Washliyah with several schools related to the education quality improvement.

\footnotetext{
6 Afifuddin and Beni Ahmad Saebani, Qualitative Research Methodology, cet. to-1, (Bandung: Pustaka Setia, 2009), p. 129.
}

${ }^{7}$ Lexy J. Moleong, Qualitative Research Methodology, cet, 18th, h. 163. 


\section{F.Data analysis technique}

Data analysis is the process of organizing and sorting data into patterns, categories and basic description unit that has a theme and can be formulated to working hypothesis formulated by the data. 8

Data analysis is the organizing data activity. The collected data can be either field notes and researchers' comments, images, photographs, documents, reports, articles and so on. The data analysis is to compile or process data that can be interpreted better. Then to process and analyze the data in this study conducted in three phases namely; reducing the data, presenting data and making inferences.

The data reduction, data presentation, and drawing conclusions on the results of research conducted at the Education Council of Al Washliyah, North Sumatra is expected to provide convenience to the reader in understanding the process and the results of this study.

\section{RESEARCH RESULTS}

A.History of Education Council of Al Washliyah

Al Washliyah is an organization that moves and start a movement in education, even raised for the role in education so that is where its existence roots. The main course immediately handled is education.A large number of schools established by $\mathrm{Al}$ Washliyah indicates the organization to be accepted by the community and has been instrumental in educating the nation. With the growing numbers from time to time, it takes management and professional supervision. Therefore the existence of Education Council of Al Washliyah is indispensable.Formation of assemblies in $\mathrm{Al}$ Washliyah in conjunction with the establishment of Al Washliyah in 1930, then resumed in 1934 after the formation of the Executive Board of $\mathrm{Al}$ Washliyah. As from 1934 Al Washliyah has moved the prepared assemblies. And for the record, the assembly formed in 1934 is different from the assembly created in the founding days of Al Washliyah.

One assembly formed is tarbiyah. The assembly deal with the education and teaching issues. Formal institution of education and teaching (tarbiyah) is known as madrasah. In East Sumatra madrasah called "mandarsah and maktab". On the ground arab maktab called by

\footnotetext{
8 Afifuddin and Beni Ahmad Saebani, Qualitative Research Methodology, cet. to-1, p. 145.
}

kuttab, derived from taktib means the teaching of writing, so kuttab means a place of teaching. ${ }^{9}$

Al Washliyah's first school was founded in Jalan Sinagar, Petisah, Medan on August 1, 1932 which called Maktab al Jam'iyatul Washliyah, which is the only home teaching and aims to educate children to be good at Islamic sciences.

On February 28, 1933 several schools owned by the Al Washliyah joined in $\mathrm{Al}$ Washliyah, as follow:

1. Madrasah Ma'sum City (Jalan Puri) led by M. Arsyad Talib Lubis.

2. Madrasah Sei Kera/ Sidodadi led by Baharuddin Ali.

3. Madrasah Kampung Sekip Sikambing led by Usman Deli.

4. Madrasah Gelugur (Gang Pensiunan) led by $\mathrm{H}$. leader Yusuf Ahmad Lubis and Sulaiman Taib.

5. Madrasah Tanjung Mulia led by Suhailuddin. ${ }^{10}$

Assembly or fields that deal specifically with the education problem was first formed in $\mathrm{Al}$ Washliyah Conference in 1934. Originally this chamber was called the Assembly of Education and Culture (MPPK) or also known as the Assembly of MT Umumi.

After three years since Al Washliyah was born, 28th February 1933, the establishment of Madrasah Al Washliyah was officially inaugurated, namely:

- Madrasah Al Washliyah Kota Ma'sum, with the teacher M. Arsyad Thalib Lubis.

- Sei Kera / Sidodadi, with the teacher Baharuddin Ali

- Kampung Sekip Sikambingweg, with the teacher Usman Deli

- Gelugur (Pensiunan) with the teacher Joseph H. Sulaiman Ahmad Lubis and Thaib

- Brayan Darat Island, with the teacher Umar Nasution

- Tanjung Mulia, with the teacher Suhailuddin ${ }^{11}$

B.Assembly's Education Workplan of $\mathrm{Al}$ Washliyah North Sumatra

Education in the broadest sense is to develop a balance in all of human personality/ protégé, through the intellectual exercise, mental, reason, feelings and attitudes of his life as a whole. Thus, education must involve all aspects in

\footnotetext{
${ }^{9}$ Chalidjah Hasanuddin, Al Jam'iyatul Washliyah Fire In Husk (Bandung: Pustaka, 1988), cet. to-1, p. 74.

10lbid., P. 76.

${ }^{11}$ Board of Al Washliyah, 1/4 Abad Al Washliyah, cet. to-1, p. 41.
} 
terms of humanity, mankind as individual beings, humans as social beings/society members and human beings as God's servant. To achieve these noble goals, Al Washliyah through its Education Council earnestly reflect on the noble values as stated in the organization's rules.

The objective conditions of the school/madrasah Al Washliyah in all levels of education have not much met the demands of the education purpose, the Education Council of $\mathrm{Al}$ Washliyah North Sumatra programmed educational planning by Perennial Knowledge methods and Acquired Knowledge oriented to Science and Technology, refering to the Education curriculum System of Al Washliyah. It was as the decision of Washliyah Council Regional XI Al in North Sumatra in terms of workplans as follows:

1. Education personnel's quality improvement.

2. Al Washliyah's database creation includes education, school data, teaching staff, number of students, infrastructure and so on. Furthermore periodically inserted into $\mathrm{Al}$ Washliyah's website.

3. Implementation of the education system $\mathrm{Al}$ Washliyah proportionally in every educational institution of Al Washliyah.

4. Providing education and training (training) education personnel in order to increase human resources.

5. Implementing the Annual Regional Meeting of Education Council in the terms of evaluation and monitoring for enhancing the education quality.

6. Improving and refining educational facilities/infrastructure and educational administration management.

C.Activities in Education Council of Al Washliyah North Sumatra

As the only assembly that is responsible in terms of education, the Education Council of $\mathrm{Al}$ Washliyah, North Sumatra has three (3) types of functions (tasks), namely:

1. Fostering general education and teaching in North Sumatra including Education Council of Al Washliyah in regencies / cities in North Sumatra.

2. Arranging the provision of education for secondary / junior high, high school, vocational school, Madrasah Aliyah, etc., including hiring and firing teachers and principals.

3. The organizer of the boarding school of $\mathrm{Al}$ Washliyah.

D.Special Research Findings
1. Education Quality Improvement Planning in Education Council of $\mathrm{Al}$ Washliyah North Sumatra

Planning is the first action in the managerial activity in every organization. Therefore, planning will determine any performance difference from one organization to another organization in carrying out a plan to achieve the goal.

Planning (planning) is one of the functions of management, then in the management of an organization, not excluding educational institutions - in this regard Education Council of $\mathrm{Al}$ Washliyah North Sumatra, which must first be made by the board is drawing up a plan for improving the performance and achievements of the institution is scalable, mature, as well as sustainable (longterm).

Regarding to the planning by Education Council of Al Washliyah, the researchers conducted an interview with Mr. Dariansyah Emde, chairman of the Education Council Al Washliyah period 2003-2010 on 16 May 2011, he argued as follows:

This plan was originally decided in $\mathrm{Al}$ Washliyah Regional Council in North Sumatra, which would have included a special commission to discuss the organization's workplanfor a period of stewardship. After that there was media decision which specifically addressed the organizational workplancalled the Regional Meeting (Rakerwil). However, it should be emphasized that any decision taken must not conflict with the decision of Al Washliyah Congress, the National Meeting and the regulations of other organizations, especially the Statutes and Bylaws of Al Washliyah. After that, the Governing Council elected by the Regional Chairman of Al Washliyah's result put into the Regional Council work plan which then becomes a guide for Education Council of Al Washliyah, North Sumatra to be implemented in the periodization of stewardship.

The above explanation states that the first activities carried out by the board in managing an organization is making plans. Because the plan is the process of determining what should have been achieved and how to make it happen in reality. It means that in the plan will be determined what is supposed to be achieved by making a plan and how to implement the plan, in 
order to achieve the objectives set managers at every level of management

Based on the above information can be known that the Education Council works on the policies of Regional Chairman of Al Wasliyah. To put it simply, the Education Council of Al Washliyah North Sumatra is the extension of $\mathrm{Al}$ Washliyah in its participation in the education world.

Drawing up plans to improve the education quality at the Education Council of $\mathrm{Al}$ Washliyah, North Sumatra is certainly not chairman's responsibilities, but based on the advice, suggestions, opinions and consideration of the entire board assembly, assembly area, the head of school / madrasah, as well as academics and practitioners as well as the parties concerned with education quality improvement, especially for Al Washliyah North Sumatra. Education Council of Al Washliyah works in accordance with the compiled workplan. According to the documents obtained by the authors there are several phases of Education Council of Al Washliyah's work plan .

Washliyah do not walk alone. They always involve other parties such as Al Washliyah schools and other board personnel. This is consistent with the expression of the Education Council chairman Al Wasliyah period 2003-2010 as follows:

To make planning in education quality improvement, Education Council of Al Washliyah perform the following steps; 1) invite the principals to the office of Education Council of Al Washliyah, 2) gather Education Council Al Washliyah's board that serves as a decision-maker, 3) discuss to establish a plan and find the best way to run a workplanwhich has been arranged beforehand.

To put it simply, Education Council of Al Washliyah seeks to build cooperation and good communication with schools under its umbrella. This is justified by Mr. Amir Hamzah Ritonga as Vice Principals (PKM 1) MTs (junior high school) Univa Medan. Based on researchers" interviews on May 23, 2011, he said:

Education Council of Al Washliyah always invite principals to plan education quality improvement in schools of Al Washliyah, which was finally implemented in each school or implemented by the board of Assembly itself to include the principal or teachers. Usually the Education Council meeting with the board of Al Washliyah has done at the beginning of the new school and the end one. It is more incidental. The meetings conducted by Education Council of Al Washliyah are only for the principal. In the end the principal must become an extension to the teachers.

The above opinion is confirmed also by $\mathrm{Mr}$. Mislan as Head of Technical Vocational Al Washliyah 1. Based on researchers" interviews on May 23, 2011, said as follows:

During my term as a principal, the policy of education quality improvement is vested and exercised to each school according to the school's conditions and ability. Activities to improve the education quality we did independently. Education Council of Al Washliyah, North Sumatra does not provide direction and guidance.

Based on an interview with the chairman of Education Council of Al Washliyah Dariansyah Emde period 2003-2010 and with the current chairman, there are several plans to improve the education quality conducted by Education Council Al Washliyah, namely:

1. Paying visit to schools Al Washliyah. Aims to look at the needs of the school in order to improve the education quality. The visiting time is not specified, but rather was incidental in certain respects only.

2. Providing education and training (training) the professionalism of teachers.

3. Holding seminars and workshops with teachers of Al Washliyah.

4. Paying study-visit to the region whose education has been developed.

5. Engaging schools, both principals or teachers in upgrading-penaranan, comparative study.

6. Provide recommendations to the teachers who have an undergraduate to study at the University of $\mathrm{Al}$ Washliyah (UNIVA) and Muslim Nusantara University (UMN) Al Washliyah.

7. Building cooperation with other educational institutions in order to get a better opportunity to improve education.

8. Fostering students to remain outstanding in their respective fields.

The above is confirmed by Shahid Hashim, Chairman of the Education Council of Al Washliyah, North Sumatra which stated that Education Council of Al Washliyah North Sumatra, which now will continue what has been planned by the previous management, as well as do repairs and improvements in various fields. 
2. Implementation of Education Quality Improvement in Education Council of $\mathrm{Al}$ Washliyah North Sumatra

\section{a. Leadership}

Chairman of the Education Council of $\mathrm{Al}$ Washliyah, North Sumatra as policy makers in education quality improvement should be able to commit as educators, managers, administrators and supervisors in the subsequent development, in accordance with the needs of society and the times. The chairman should also be able to act as a leader, innovator and motivator in the neighborhood of Education Council of $\mathrm{Al}$ Washliyah, North Sumatra. Thus the new paradigm of educational management which requires that the chairman should be able to function as an educator, manager, administrator, supervisor, leader, innovator and motivator can be properly achieved.

Advanced perspective hinted that the leadership of educational institutions must be able to act as a mediator and figure for society and environment development. Thus the responsibility of education council is increasingly rising. In the structure and composition of the Assembly, the chairman does not work alone but is assisted by the deputy chairman, the secretary, the deputy secretary, treasurer, deputy treasurer, secretarial staff and others.

Based on researchers' interviews with chief of Education Council of Al Washliyah North Sumatra stated that:

$A$ head of Education Council of Al Washliyah North Sumatra, carrying out his work as a leader, administrator, innovator and supervisors, is directly responsible to the Regional Chairman of Al Washliyah North Sumatra. In addition, the chairman of the Education Council of Al Washliyah North Sumatra must establish cooperation and good relations with all heads of schools / madrasah Al Wasliyah North Sumatra, which will continuously be involved in any policy issued by the Board of Education Al Washliyah North Sumatra.

The above information is in accordance with observations the researchers did on 24 May 2011. Education Council of Al Washliyah, North Sumatra held a coordination meeting with the entire board and the entire head of the school / madrasah of Al Washliyah North Sumatra at Regional Chairman's hall of Al Wasliyah North Sumatra. The meeting was chaired by the chairman of Education Council of Al Washliyah, North Sumatra . The agenda were: 1) the direction of the chairman of $\mathrm{Al}$ Washliyah Regional Chairman of North Sumatra, 2) briefing and introduction of the stewardship of Education Council of Al Washliyah, North Sumatra 20112015 period, 3) greetings the entire board of Education Council of $\mathrm{Al}$ Washliyah, North Sumatra with all heads of schools / madrasah present.

The results of document observations the researchers did also show some leadership activities related to the improvement of education quality as shown in the following table:

Table. 1.

Activity Leadership Education Council Al Washliyah North Sumatra.

\begin{tabular}{|c|c|c|c|}
\hline $\begin{array}{l}\mathbf{N} \\
\mathbf{0 .}\end{array}$ & $\begin{array}{l}\text { Date / } \\
\text { Month / } \\
\text { Year }\end{array}$ & The place & activity \\
\hline 1 & $\begin{array}{l}\text { June, } 21^{\text {st }} \\
2004\end{array}$ & EX PGA UNIVA & $\begin{array}{l}\text { Principal Election } \\
\text { Briefing }\end{array}$ \\
\hline 2 & $\begin{array}{l}\text { June, } 25^{\text {th }} \\
2004\end{array}$ & Aliyah UNIVA & $\begin{array}{l}\text { Principal Election } \\
\text { Briefing }\end{array}$ \\
\hline 3 & July, $1^{\text {st }} 2004$ & SMP 8 AW UNIVA & Principal Election \\
\hline 4 & $\begin{array}{l}\text { July, } 10^{\text {th }} \\
2004\end{array}$ & Aliyah Mu'allimin & Principal Election \\
\hline 5 & $\begin{array}{l}\text { July, } 21^{\text {st }} \\
2004\end{array}$ & Berastagi & $\begin{array}{l}\text { Meeting of Heads } \\
\text { Qismul'Ali }\end{array}$ \\
\hline 6 & July 2005 & Jakarta & $\begin{array}{l}\text { The } 1^{\text {st }} \text { National } \\
\text { Education } \\
\text { Conference of Al } \\
\text { Washliyah }\end{array}$ \\
\hline 7 & $\begin{array}{l}\text { January } 6^{\text {th }}- \\
8^{\text {th }} 2006\end{array}$ & $\begin{array}{l}\text { Mes Pemprovsu } \\
\text { local government } \\
\text { in Brastagi }\end{array}$ & $\begin{array}{l}\text { Discussion } \\
\text { Organizers Legal } \\
\text { Entity (BHP) } \\
\text { Al Washliyah }\end{array}$ \\
\hline 7 & $\begin{array}{l}\text { July } 5^{\text {th }}-7^{\text {th }} \\
2006\end{array}$ & Batam & $\begin{array}{l}\text { The } 2^{\text {nd }} \text { National } \\
\text { Education } \\
\text { Conference of } \\
\text { Al Washliyah }\end{array}$ \\
\hline 8 & July 2009 & $\begin{array}{l}\text { Lembang - West } \\
\text { Java }\end{array}$ & $\begin{array}{l}\text { Following the } \\
\text { National Education } \\
\text { Conference of } \mathrm{Al} \\
\text { Washliyah }\end{array}$ \\
\hline
\end{tabular}

Source: Report of the Education Council Al Washliyah North Sumatra.

\section{b. Education and Training}

In order to improve the quality, education and training, it is very important for educational actors in their efforts to develop a more directional, professional, programmed pattern with the reliable ability of the human resources. The education and training is expected to give birth to human beings with superior competence and insight to support the needs of education quality improvement.

The personnels in Education Council of $\mathrm{Al}$ Washliyah North Sumatra are mostly the educational practitioners who are experienced in the management process of education, with 
current compositions, really no doubt is the ability of the assembly personnel to implement such superior education management. The head of the school / madrasah, teachers and all related roles are targeted by Education Council of $\mathrm{Al}$ Washliyah to be trained and educated as professional educators.

Since the educators in the educational process play a strategic role especially to form a national character through the development of personality and values, in the view of the learning dimension, the role of educators in Indonesian society remains dominant even though the technology can be utilized in the very fast learning process. This is because there are dimensions of the educational process, or more specifically, the learning process, played by educators that can not be replaced by any technology. Their functions would not be entirely eliminated as educators and teachers for learners.

That is why teachers must be prepared carefully, respecting to the demands of professionalism towards educators, the more he felt the urge to improve the quality of teachers, in order to ensure achievement of education quality improvements at all levels. This is confirmed by the head of Madrasah Aliyah Al Washliyah Al Qismul 'Aly as follows:

Talking about preparing teachers means closely related to the improvement of human resources which then becomes a source of strength for the organization of education (madrasas). If the human resources, including in education, have sufficient competence to the demands of the profession, then the achievement of educational goals will be achieved as well. A teacher as an educator and an example of the students' future, obviously require sufficient competence so that the learning process carried out can give a significant influence for the students' development in increasingly competitive situation. A teacher is effective in providing teaching and learning as well as combining its competence with its performance in achieving the objectives.

Related to the above explanation, it is understood about how important is the teachers' competence in education quality improvement in the school / madrasah Al Washliyah specifically. There are several ways in which the Education Council of Al Washliyah, North Sumatra in order to improve the education quality, one of which is hold or engage teachers in a variety of training in line with the demands of the education world. As explained by Dariansyah Emde:

We realize that one of the most important part in education quality improvement is the teacher. Teachers who see and feel the presence of the students directly. Therefore, teachers must have a good competence in their own field. Efforts to improve the quality of teachers have been done by Education Council of Al Washliyah, including: organizing various training, seminary, and upgrading, both as an organizer as well as an agent that sends these teachers to join the activities organized by the government and other institutions.

It is also disclosed by one of the administrators of Education Council of $\mathrm{Al}$ Washliyah, North Sumatra in the interview as follows:

That quality improvement efforts conducted by the Education Council of Al Washliyah, North Sumatra during a fiveyears period is about 7 times, such as a library training, competency-based curriculum training, teacher training, study and sports and arts. And once it isfinished executing these activities, we always keep a record of the activities in our files.

Apart from limited education and training, Education Council of Al Washliyah North Sumatra made another attempt to encourage teachers to attend training conducted by the government, such as certification, it is as expressed by the Head of Madrasah Aliyah Al Qismul 'Aly in interviews on May 20, 2011:

Since Education Council Al Washliyah rarely conducted training for educational staff, we encourage our uncertified teachers to join, this is of course to improve the quality of our teachers' in order to become professional teachers. We continue to conduct intensive data collection to those teachers who have not been certified. While for the teachers who have been certified we will monitor their competence development.

Here the researchers suggest some training related to education quality improvement that have been implemented by Education $\mathrm{Al}$ Washliyah North Sumatra: 
Table 2.

Education and Training, Competition, Seminar, and Workshop by Education Council of Al Washliyah, North Sumatra

\begin{tabular}{|c|c|c|c|}
\hline $\begin{array}{l}\mathbf{N} \\
\mathbf{0}\end{array}$ & $\begin{array}{c}\text { Date / } \\
\text { Month / } \\
\text { Year } \\
\end{array}$ & Venue & Activity \\
\hline 1 & Jan 2004 & $\begin{array}{l}\text { - } \text { MTs (junior high } \\
\text { school).S Al } \\
\text { Washliyah } \\
\text { Belawan } \\
\text { - } \text { MTs (junior high } \\
\text { school).S Al } \\
\text { Washliyah } \\
\text { UNIVA }\end{array}$ & $\begin{array}{l}\text { Teachers' Upgrading and } \\
\text { Guidance }\end{array}$ \\
\hline 3 & $\begin{array}{l}\text { March } \\
2004\end{array}$ & $\begin{array}{ll}\text { - } & \text { Nusantara } \\
\text { Muslim } \\
\text { University } \\
\text { (UMN) Al } \\
\text { Washliyah } \\
\text { - } & \text { MTs (junior } \\
\text { high school).S } \\
\text { Al Washliyah } \\
\text { Tembung } \\
\end{array}$ & $\begin{array}{l}\text { Upgrading Competency- } \\
\text { Based Curriculum } \\
\text { upgrading Student }\end{array}$ \\
\hline 4 & $\begin{array}{l}2^{\text {th }}-2^{\text {th }} \\
\text { August } \\
2004\end{array}$ & $\begin{array}{l}\text { North Sumatra } \\
\text { Government's Mess } \\
\text { Brastagi }\end{array}$ & $\begin{array}{l}\text { Curriculum Level } \\
\text { Arranging Madrasah } \\
\text { Aliyah Al Qismul and } \\
\text { Madrasah Aliyah } \\
\text { Mu'allimin } \\
\end{array}$ \\
\hline 5 & $\begin{array}{l}12^{\text {th }}-15^{\text {th }} \\
\text { Septembe } \\
\text { r } 2004\end{array}$ & Solo & $\begin{array}{l}\text { Borading School } \\
\text { Seminary } \\
\text { in Indonesia }\end{array}$ \\
\hline 6 & July 2005 & Jakarta & $\begin{array}{l}\text { The } 1^{\text {st }} \text { National } \\
\text { Education Congress of } \mathrm{Al} \\
\text { Washliyah }\end{array}$ \\
\hline 7 & $\begin{array}{l}\text { January } \\
6^{\text {th }}-8^{\text {th }} \\
2006 \\
\end{array}$ & $\begin{array}{l}\text { Pemprovsu local } \\
\text { government's mess } \\
\text { in Brastagi }\end{array}$ & $\begin{array}{l}\text { Discussion Organizers } \\
\text { Legal Entity } \\
\text { Al Washliyah }\end{array}$ \\
\hline 8 & $\begin{array}{l}25^{\text {th }}-26^{\text {th }} \\
\text { March } \\
2006\end{array}$ & Asrama Haji Medan & $\begin{array}{l}\text { Workshop of } \\
\text { Socialization Law No. } 14 \\
\text { Year } 2005 \text { on Teachers } \\
\text { and Lecturers }\end{array}$ \\
\hline 9 & $\begin{array}{l}\text { July } 5^{\text {th }}- \\
7 \text { th, } 2006\end{array}$ & Batam & $\begin{array}{l}\text { The } 2^{\text {nd }} \text { National } \\
\text { Education Congress of } \mathrm{Al} \\
\text { Washliyah }\end{array}$ \\
\hline $\begin{array}{l}1 \\
0\end{array}$ & $\begin{array}{l}\text { July } 24^{\text {th }}- \\
27^{\text {th }} \\
2006\end{array}$ & Semarang & $\begin{array}{l}\text { National Education } \\
\text { Seminar by the } \\
\text { Indonesian Teachers } \\
\text { Association (PGRI) }\end{array}$ \\
\hline $\begin{array}{l}1 \\
1\end{array}$ & $\begin{array}{l}\text { December } \\
25^{\text {th }} \\
2006 \\
\end{array}$ & $\begin{array}{l}\text { Aula UMN Al } \\
\text { Washliyah }\end{array}$ & $\begin{array}{l}\text { Dissemination } \\
\text { Competency-Based } \\
\text { Curriculum } \\
\end{array}$ \\
\hline $\begin{array}{l}1 \\
2 \\
\end{array}$ & $\begin{array}{l}\text { Septembe } \\
\text { r } 2007\end{array}$ & $\begin{array}{l}\text { Al Washliyah North } \\
\text { Sumatra }\end{array}$ & $\begin{array}{l}\text { Elementary School } \\
\text { Curriculum Seminary }\end{array}$ \\
\hline $\begin{array}{l}1 \\
3\end{array}$ & $\begin{array}{l}\text { January } \\
2008\end{array}$ & $\begin{array}{l}\text { Al Washliyah North } \\
\text { Sumatra }\end{array}$ & $\begin{array}{l}\text { MTs (junior high school) } \\
\text { level Curriculum } \\
\text { Workshop }\end{array}$ \\
\hline $\begin{array}{l}1 \\
4\end{array}$ & $\begin{array}{l}\text { February } \\
7^{\text {th }}-8^{\text {th }} \\
2009\end{array}$ & $\begin{array}{l}\text { Al Washliyah North } \\
\text { Sumatra }\end{array}$ & $\begin{array}{l}\text { Students Competition for } \\
\text { SD / MI Al Washliyah } \\
\text { throughout North } \\
\text { Sumatra (science and } \\
\text { mathematics olympiade, } \\
\text { speech contest and the } \\
\text { Qur'an recitation) }\end{array}$ \\
\hline $\begin{array}{l}1 \\
5\end{array}$ & July 2009 & $\begin{array}{l}\text { Lembang - West } \\
\text { Java }\end{array}$ & $\begin{array}{l}\text { The } 3^{\text {rd }} \text { National } \\
\text { Education Congress of } \mathrm{Al} \\
\text { Washliyah }\end{array}$ \\
\hline $\begin{array}{l}1 \\
6\end{array}$ & $\begin{array}{l}\text { Novembe } \\
\text { r } 2009\end{array}$ & $\begin{array}{l}\text { Hall UMN Al } \\
\text { Washliyah Terrain }\end{array}$ & $\begin{array}{l}\text { Library Officer Training } \\
\text { for School / Madrasah Al } \\
\text { Washliyah }\end{array}$ \\
\hline
\end{tabular}

Source: Report of the Education Council of Al Washliyah, North Sumatra in 2011

Another form of policy carried out by the Education Council Al Washliyah related to education in order to improve the academic qualifications of teachers, the Education Council of Al Washliyah North Sumatra appealed to teachers who have a bachelor in order to continue their education. But it is merely an appeal that is not accompanied by sanctions if it is not heeded. Education Council of Al Washliyah provides such recommendation if the teacher wants to continue her education at the University of Al Washliyah and Muslim Nusantara University (UMN) Al Washliyah, because the two colleges are owned by Al Washliyah managed by the Board of Al Washliyah.

The policy of Education Council of $\mathrm{Al}$ Washliyah, North Sumatra, that appealed to the fresh-graduate teachers to continue their bachelor-degree education, is an effort to the organization's concern to teachers's career and professionalism and to improve the teachers'qualifications as well as carry out the mandate of the Law on Teachers and Lecturers Article 9: "Academic Educators Qualifications must be Bachelor Degree or Diploma Degree", and Government Regulation, Article 29 paragraph (1) point a:" The Minimum Educators Academic Qualifications is Diploma (IV) or Bachelor ".

\section{c. Communication}

In terms of communication, there are two things to be done by the Board of Education Council of Al Washliyah North Sumatra: direct communication via mail or by other telecommunications (telephone, mobile phone). Both of these media are connective information related to the development of the school / madrasah or other information related to education. But specifically regarding to correspondence activity with schools / madrasah obliged to submit information on the school / madrasah's progress periodically, apparently not all do so. It is as stated by a representative of the Secretary of the Education Council of Al Washliyah North Sumatra that register all correspondence both incoming and outgoing mail, as follows:

If they're only several school or madrasah which often make a written hich, amwong are Madrasah Al Washliyah Tanjung Pura, Madrasah / School Al Washliyah Marbau, Madrasah Al Washliyah Central Tapanuli, the rest never do. This is because there are no sanctions or penalties imposed if they did not send it.

According to the regulations in the Education System in Al Washliyah, that every school is required to submit a written report to Education Council Al Washliyah, 
but the school / madrasah does not entirely follow the letter we sent, although we have done several times. Indeed the school / madrasah's obedience is currently very low.

One good way to communicate directly is visit to units of Al Washliyah school, and to take the comparison also visit the outside institutions, with hope of positive things that allows to be applied in educational institutions Al Washliyah:

Table 3.

Comparative Study Visits and Education Council of Al Washliyah North Sumatra

\begin{tabular}{|c|c|c|c|}
\hline No. & $\begin{array}{l}\text { Date / } \\
\text { Month / } \\
\text { Year } \\
\end{array}$ & The place & activity \\
\hline 1 & Jan 2004 & $\begin{array}{l}\text { MAS Mu'allimin } \\
\text { UNIVA }\end{array}$ & $\begin{array}{l}\text { Release of Hajj } \\
\text { Practice. }\end{array}$ \\
\hline 2 & $\begin{array}{l}\text { February } \\
2004\end{array}$ & Kedah - Malaysia & $\begin{array}{l}\text { The comparative } \\
\text { study together UMN } \\
\text { Al Washliyah }\end{array}$ \\
\hline 3 & $\begin{array}{l}\text { March } \\
2004\end{array}$ & $\begin{array}{l}\text { UMN Al Washliyah at } \\
\text { Wisma Benteng }\end{array}$ & $\begin{array}{l}\text { Attending } \\
\text { graduation } \\
\text { ceremony }\end{array}$ \\
\hline 4 & June 2004 & $\begin{array}{l}\text { 1. Borading School } \\
\text { of Al Washliyah } \\
\text { Tanjung Labuhan } \\
\text { Batu Haloban } \\
\text { 2. MTs (junior high } \\
\text { school) } \\
\text { Mu'allimin UNIVA } \\
\text { 3. Madrasah Al } \\
\text { Washliyah } \\
\text { Completed Kab. } \\
\text { langkat } \\
\text { 4. MTs (junior high } \\
\text { school) Al } \\
\text { Washliyah } \\
\text { Sigambal } \\
\text { Labuhan Batu } \\
\text { 5. Madrasah Al } \\
\text { Washliyah } \\
\text { Serbelawan } \\
\text { Simelungun }\end{array}$ & $\begin{array}{l}\text { Visits and coaching } \\
\text { Students' graduation } \\
\text { Visits and coaching } \\
\text { Attending students' } \\
\text { farewell } \\
\text { Visits and coaching }\end{array}$ \\
\hline 5 & $\begin{array}{l}\text { June } 30^{\text {th }} \\
2004\end{array}$ & $\begin{array}{l}\text { Madrasah Al } \\
\text { Washliyah } \\
\text { Perbaungan } \\
\end{array}$ & Visit \\
\hline 6 & $\begin{array}{l}13^{\text {th }}-15^{\text {th }} \\
\text { January } \\
2005\end{array}$ & Asahan & $\begin{array}{l}\text { Visits to Schools / } \\
\text { Madrasah Al } \\
\text { Washliyah in Asahan }\end{array}$ \\
\hline 7 & $\begin{array}{l}12^{\text {th }}-17^{\text {th }} \\
\text { February } \\
2007\end{array}$ & $\begin{array}{l}\text { Schools and } \\
\text { Universities in } \\
\text { Malaysia } \\
\end{array}$ & Comparative study \\
\hline 8 & $\begin{array}{l}7^{\text {th }}-12^{\text {th }} \\
\text { July } 2008\end{array}$ & $\begin{array}{l}\text { Malaysia and } \\
\text { Thailand }\end{array}$ & $\begin{array}{l}\text { Comparative Study } \\
\text { at Schools in } \\
\text { Malaysia and the } \\
\text { University of Yala in } \\
\text { Thailand }\end{array}$ \\
\hline 9 & $\begin{array}{l}\text { February } \\
8^{\text {th }}, 2009\end{array}$ & $\begin{array}{l}\text { Regional Office of Al } \\
\text { Washliyah North } \\
\text { Sumatra }\end{array}$ & $\begin{array}{l}\text { Teachers / } \\
\text { Madrasah } \\
\text { Al Washliyah } \\
\text { Gathering in North } \\
\text { Sumatra }\end{array}$ \\
\hline 10 & $\begin{array}{l}\text { July } 24^{\text {th }}- \\
30^{\text {th }} 2010\end{array}$ & $\begin{array}{l}\text { Jakarta, Yogyakarta, } \\
\text { Magelang, Cirebon, } \\
\text { Bandung }\end{array}$ & $\begin{array}{l}\text { School / Madrasah } \\
\text { Gathering in Java }\end{array}$ \\
\hline
\end{tabular}

Source: Report of the Education Council of $\mathrm{Al}$ Washliyah, North Sumatra in 2011

\section{d. Rewards and Recognition}

Recognition or reward or award is intended to provide motivation so from time to time there is an increase of every activity. Besides, a certificate or letter of appreciation received can also be used as a tool to add value in terms of teacher's certification and other requirements related to improved performance and benefits in education careers.

In accordance with the results of interview with Deputy Head of MTs (junior high school) Al Washliyah UNIVA and Head of Madrasah Aliyah Al Washliyah Al Qismul 'Aly, Education Council of Al Washliyah, North Sumatra reward a certificate or letter of appreciation for participating in education and training activities conducted.

Although it does not take place on a regular basis, via Education Council Al Washliyah North Sumatra, the school in the assessment is an adhere unit to the organization so deserves appreciation, then received the aid from the government in varied value and amount. However, due to changing government policies related to delivering aid, Education Council of $\mathrm{Al}$ Washliyah, North Sumatra no longer act as the party who distribute the aid, because the aid is directly to the school / madrasah concerned.

From the above discussion, the Chairman emphasized with explanations Education Council of Al Washliyah as follows:

To the School or the teachers who join the training, we give them an award plaque, because it is important for them, and a few years ago, around 2005-2008 we are also distributing aid in the form of money we get from the provincial budgeting to obedient and subservient school / madrasah to Al Washliyah, and we adjust the amount. It was a form of attention to them.

Based on the above information, it is clear that Education Council of Al Washliyah, North Sumatra always give appreciation to the school to make efforts to increase the education quality. Besides, Education Council of Al Washliyah, North Sumatra has given the widest possible opportunity to do improvements.

\section{CONCLUSION}

The improved quality is becoming increasingly important for educational institutions in order to achieve the fullest educational goals and to gain public confidence. Educational institutions must demonstrate that they are able to provide quality education to the 
learners. We live in an era of all-round unclear competition. To be closer to improving the quality itself, the authors take us all in the theoretical concepts of the quality.

\section{BIBLIOGRAPHY}

[1] AD/ART Al Washliyah. Jakarta: PB Al Washliyah, 2010.

[2] Admodiwiro, Soebagio. Manajemen Pendidikan Indonesia, Jakarta: Ardadijaya, 2000.

[3] Afifuddin dan Beni Ahmad Saebani. Metodologi Penelitian Kualitatif, Bandung: Pustaka Setia, 2009.

[4] Arcaro S Jerome. Pendidikan Berbasis Mutu: Prinsip-Prinsip Perumusan Dan Tata Langkah Penerapan, Yogjakarta: Pustaka Pelajar, 2005

[5] Azizy, Ahmad Hamim. Al Jam'iyatul Washliyah dalam Kancah Politik Indonesia, Banda Aceh: Pena, 2006.

[6] Batubara Ismet, dan Ja,far. Bunga Rampai Al Jam'iyatul Washliyah, Banda Aceh: Al Washliyah University Press, 2010.

[7] Fattah, Nanang. Landasan Manajemen Pendidikan, Bandung: Remaja Rosdakarya, 1999.

[8] Hadis, Abdul dan Nurhayati. Manajemen Mutu Pendidikan, Bandung: Alfabeta, 2010.

[9] Hasan. Guru yang Profesional, Bandung: UPI, 2004.

[10] Hasanuddin, Chalidjah. Al Jam'iyatul Washliyah Api dalam Sekam, Bandung: Pustaka, 1988

[11] Himpunan Peraturan Perundang-Undangan Sistem Pendidikan Nasional.

Bandung: Fokusmedia, 2009.

[12] Imam Gojali, dan Umiarso. Manajemen Mutu Sekolah di Era Otonomi Pendidikan Jogyakarta: IRCiSoD, 2010.

[13] Ibn Muhammad Ismail Al-Bukhari, Abu Abdullah. Sahih Bukhari, Beirut: Dar AsSarbu, t.t,

[14] Kementerian Agama RI. Syaamil Al Qur'an: Miracle The Reference, Bandung: PT Sygma Publishing, 2010.

[15] Muhadjir. Perencanaan dan Kebijakan Pengembangan SDM, Yogyakarta: Rake Sarasin, 1992.

[16] Mulyasa. E. Menjadi Kepala Sekolah Profesional, Bandung: Remaja Rosdakarya, 2007.

[17] Munawar, Rofi. Manajemen Organisasi Dalam Al Qur'an, Artikel, wanvisioner.blogspot.com, 2009.
[18] Moleong, Lexy J. Metodologi Penelitian Kualitatif, Bandung: Remaja Rosdakarya, 2000.

[19] Nasution, M.N. Manajemen Mutu Terpadu, Bogor: Ghalia Indonesia, 2005.

[20] Nata, Abuddin. Manajemen Pendidikan, Jakarta: Kencana, 2003.

[21] Pengurus Besar Al Jam'iyatul Washliyah. 1/4 Abad Al Jam'iyatul Washliyah, Medan: PB Al Washliyah, 1955.

[22] Pengurus Besar Al Jam'iyatul Washliyah. Sistem Pendidikan Al Washliyah, Jakarta: PB Al Washliyah, 2010

[23] Rachman Shaleh, Abdul. Madrasah dan Pendidikan Anak Bangsa, Visi, Misi dan Aksi, Jakarta: Raja Grafindo Persada, 2004.

[24] Sallis, Edward. Manajemen Mutu Terpadu Pendidikan, Yokyakarta: IRCiSoD, 2010.

[25] Syafaruddin. Manajemen Lembaga Pendidikan Islam, Jakarta: PT. Ciputat Press, 2005

[26] Syafaruddin. Mnajemen Mutu Terpadu dalam Pendidikan (Konsep, Strategi, dan Aplikasi), Jakarta: PT. Garasindo, 2002

[27] Sukmadinata. Nana Saodih, Pengendalian Mutu Pendidikan Sekolah Menengah, Bandung: PT. Refika Aditama, 2006.

[28] Sulipan. Pengembangan Profesi Guru, Kepala Sekolah dan Pengawas, Artikel, Sulipan@yahoo.com, 2011.

[29] Sutopo. Administrasi Manajemen dan Organisasi, Jakarta: Lembaga Administrasi Negara, 1999.

[30] Sukandar. Undang-Undang Republik Indonesia Nomor 14 Tahun 2005 tentang Guru dan Dosen, Jakarta: Pustaka Candra, 2006.

[31] Thoha, Miftah. Kepemimpinan dalam Manajemen, Jakarta: Raja Grafindo Persada, 1995.

[32] Tilaar. Manajemen Pendidikan Nasional. Kajian Pendidikan Masa Depan, Bandung: Remaja Rosdakarya, 1997.

[33] Tim Dosen Administrasi Pendidikan UPI. Manajemen Pendidikan, Bandung: Alfabeta, 2010.

[34] Usman, Husaini. "Peran Baru Administrasi Pendidikan dari Sistem Sentralistik Menuju Sistem Desentralistik", dalam Jurnal Ilmu Pendidikan (Februari 2001), JIlid 8. 